\title{
RELATIONSHIP BETWEEN THE MORPHOLOGIC ALTERATIONS OF VOCAL CORDS FROM ADULT AUTOPSIES AND THE CAUSE OF DEATH
}

\author{
Ana Karina Marques Salge, Eumenia Costa da Cunha Castro, Mara Lúcia Fonseca \\ Ferraz, Marlene Antônia dos Reis and Vicente de Paula Antunes Teixeira
}

\begin{abstract}
SALGE AKM et al. - Relationship between the morphologic alterations of vocal cords from adult autopsies and the cause of death. Rev. Hosp. Clín. Fac. Med. S. Paulo 59(2):63-66, 2004.
\end{abstract}

PURPOSE: The purpose of this study was to identify the possible alteration in the thickness of the epithelium basal membrane of the vocal cords and correlate it with the cause of death.

METHOD: Larynxes collected from adult autopsies during the period of 1993 to 2001 were utilized. We used the hematoxylin-eosin and periodic acid-Schiff staining methods for the morphological and morphometric analysis.

RESULTS: Sixty-six vocal cords were analysed; increased thickness was identified in 14 cases (21.2\%), with equal proportions between the genders. Increased vocal-cord thickness was more frequent in patients of the white ethnicity (12 cases, $85.7 \%)$. Respiratory alterations were found in $10(71.4 \%)$ of the cases with increased vocal-cord thickness. Of the patients that were maintained with mechanical ventilation before death, 7 (18.4\%) had thickening of the basal membrane. Among the smokers, 9 (19.63\%) had basal membrane thickening.

CONCLUSION: No statistically significant differences were found between the cases in which the cause of death was related to respiratory diseases as compared to non-respiratory diseases and the thickening of the basal membrane of the vocal cords. However, new studies are needed in order to verify the etiopathogenesis of this thickening.

KEY WORDS: Adults. Autopsy. Basal membrane. Thickness. Vocal cords.

Vocal cords are pearl-white colored structures found in the glottis cavity ${ }^{1-}$ ${ }^{3}$. The ventricular folds or false vocal cords are transversal folds that stand out in the mucous membrane of the larynx. The true vocal cords have a membrane-like part called an elastic cone or thyroarytenoid ligament ${ }^{4}$. The true vocal cords are covered by a nonkeratinized stratified epithelium that rests atop the basal membrane.

Study of the vocal cords has revealed the existence of lesions related to alterations in the basal membrane. Aside from its role among the normal biological phenomena, the role of the basal membrane has been described by several au- thors in innumerous diseases, such as the blistering disease of the skin $^{5}$, renal diseases such as the Alport syndrome ${ }^{6}$, and the diabetic glomerulopathy ${ }^{1-3}$. Lesions of the vocal cords are common in material from pediatric autopsy ${ }^{7}$. In earlier studies the role of the basal membrane of the vocal cords was thought to be related to sudden infant death syndrome. However, more recent studies have shown that this lesion is not related to sudden infant death syndrome ${ }^{8}$ and that

From the General Pathology Division of the Triângulo Mineiro Medical School Uberaba/MG, Brazil.

Received for publication on April 02, 2003. it is the most commonly found lesion in autopsies of children below 1 year of age who have died for a variety of reasons ${ }^{7}$. In adults, the thickening of the basal membrane of the vocal cords has been found to be related to benign lesions of the vocal cords, most often as a response to vibrating effects ${ }^{1,2}$, infectious diseases such as tuberculosis ${ }^{9}$, and accidents or surgeries ${ }^{10}$.

The purpose of this study is to identify the possible morphological alterations of the basal membrane of the vocal cords and thus to attempt to identify an association between these alterations and the cause of death of autopsied adults. 


\section{METHOD}

Larynxes from 66 adults autopsied during 1993 to 2001 in our school hospital were used. All subjects underwent a complete autopsy that included the collection of the larynxes. Information about gender, ethnicity, age, history of smoking, and intubation was gathered from the subjects' medical records, and the final cause of death was obtained from the autopsy report. Subjects that presented cause of death as diseases related to the respiratory tract such as pneumonia, tuberculosis, pulmonary edema, and others were classified in the Respiratory Alterations group. All other subjects with the cause of death not related to respiratory diseases were classified in the Non-respiratory Alterations group.

The larynx was transversely sectioned at points above and below the glottis cavity, with a $3 \mathrm{~cm}$ distance between the 2 points. The fragment was placed in a $10 \%$ formalin solution. After fixation, sections were cut with a 2 $\mathrm{mm}$ thickness and were embedded in paraffin $^{11}$. The fragment was then histologically processed.

Sections were processed using hematoxylin and eosin, and periodic acid-Schiff stains. Afterwards the basal membrane of the epithelium of the vocal cords was measured. Measurements were taken by using an interactive image analyzer system (MOPVIDEOPLAN $^{\circledR}$; Kontron Eletronik;
Germany). The thickness of the basal membrane of the epithelium of the vocal cords from each adult was estimated by making 5 uniformly distributed measurements of the basal membrane in the visible area of the screen. The measurements were performed under 40X light microscopy.

An electronic databank was prepared for the statistical analysis. Afterwards, the normal and homoscedastic distribution were analyzed using the parametric tests, Student's $t$-test and analysis of variance. Otherwise, nonparametric tests were used, such as the Mann-Whitney test and the KruskalWallis test. The proportions were compared using the chi-square test along with Fisher's exact test. In the correlation between the variables with a normal distribution, Pearson's correlation coefficient was used; otherwise, Spearman's coefficient was applied. The differences were considered to be statistically significant whenever $P$ was smaller than $5 \%(P<0.05)$.

\section{RESULTS}

Sixty-six vocal cords were analyzed, and information concerning gender, smoking habits, age, and ethnicity of the patients is listed on table 1. The thickening of the basal membrane of the vocal cords was identified in 14 cases $(21.2 \%)$ in which the inflammatory reaction was the most fre- quently found lesion (Table 2).

Among the cases studied, 31 $(46.96 \%)$ vocal cords were considered normal (Table 2; Fig. 1) and 14 $(21.21 \%)$ vocal cords considered thickened (Table 2; Fig. 2). The thickening of the basal membrane of the vocal cords was more frequent in white patients, 12 cases $(85.7 \%)$. The median age in the cases without or with thickening of the basal membrane of the vocal cords was 48 and 55 years, respectively. Of the 35 (53\%) cases with respiratory alterations, thickening of the basal membrane of the vocal cords was identified in $10(28.6 \%)$ cases (Table 3$)$. Among the 38 (57.5\%) intubated patients, 7 (18.4\%) presented vocal cord basal membrane thickening. There was no statistically significant relationship of gender, ethnicity, age group, smoking, or intubation to the thickening of the basal membrane of the vocal cords. Concerning the cause of death, there were no statistically significant differences between the cases in which the cause of death was related to either respiratory diseases or non-respiratory diseases and the diagnosis of thickened basal membrane of the vocal cords.

\section{DISCUSSION}

This study demonstrated that the thickening of the basal membrane of the vocal cords is found in adults with-

Table 1 - Demographic analysis of autopsied subjects from which vocal cords were collected.

\begin{tabular}{|c|c|c|c|c|c|c|c|c|c|c|}
\hline \multicolumn{11}{|c|}{ Sample $(N=66)$} \\
\hline \multicolumn{3}{|l|}{$\overline{\mathrm{Age}}$} & \multicolumn{2}{|c|}{ Ethnicity } & \multicolumn{2}{|l|}{ Gender } & \multicolumn{2}{|c|}{ Intubation } & \multicolumn{2}{|c|}{ Smoking } \\
\hline Median & MAX & MIN & White & Not White & Female & Male & Yes & No & Yes & No \\
\hline 52 & 91 & 23 & 55 & 11 & 24 & 42 & 38 & 28 & 46 & 20 \\
\hline \multicolumn{11}{|c|}{ Basal membrane vocal cords thickening sample. $(\mathrm{N}=14)$} \\
\hline \multicolumn{3}{|l|}{$\overline{\text { Age }}$} & \multicolumn{2}{|c|}{ Ethnicity } & \multicolumn{2}{|l|}{ Gender } & \multicolumn{2}{|c|}{ Intubation } & \multicolumn{2}{|c|}{ Smoking } \\
\hline Median & MAX & MIN & White & Not White & Female & Male & Yes & No & Yes & No \\
\hline 55 & 91 & 23 & 12 & 2 & 7 & 7 & 7 & 7 & 9 & 5 \\
\hline
\end{tabular}

MAX = Maximum value; MIN = Minimum value. 
out any influence of gender, ethnicity, or age group. Some authors report difficulty in analyzing information concerning data contained in autopsy reports, which may lead to difficulty in quantifying the incidence of certain diseases in a specific ethnic group ${ }^{12}$. Many lesions have been described as a consequence of intubation, for example the relationship between the ul- ceration of the epithelium of the vocal cords and intubation ${ }^{13}$. Nevertheless, upon analyzing the relationship between the thickening of the basal membrane of the vocal cords, smoking, and intubation, no significant association was found.

In spite of the fact that lesions to the vocal cords are common in pediatric autopsy ${ }^{14,7}$, there are few

Table 2 - Description of lesions of vocal cords from autopsied subjects.

\begin{tabular}{ll}
\hline Lesion & $\mathrm{N}(\%)$ \\
\hline Normal & $31(46.96 \%)$ \\
Inflammatory infiltration & $17(25.75 \%)$ \\
Vocal cord basement membrane thickening & $14(21.21 \%)$ \\
Hemorrhage & $4(6.06 \%)$ \\
\hline
\end{tabular}

studies published on this subject. Our study found the same incidence of the thickening of the basal membrane of the vocal cords in adults as those published about children younger than 1 year of age $\mathrm{e}^{7}$. The ultrastructure of the vocal cords has been well studied, demonstrating its intrinsic constitution $^{1}$. Nevertheless, the mechanism for the formation of the thickened basal membrane is not well known. The fact that we found the same incidence for the thickening of the basal membrane of the vocal cords in adults and children raises the hypothesis that this lesion in adults could be chronic instead of acute, as those lesions found in children appear to be.

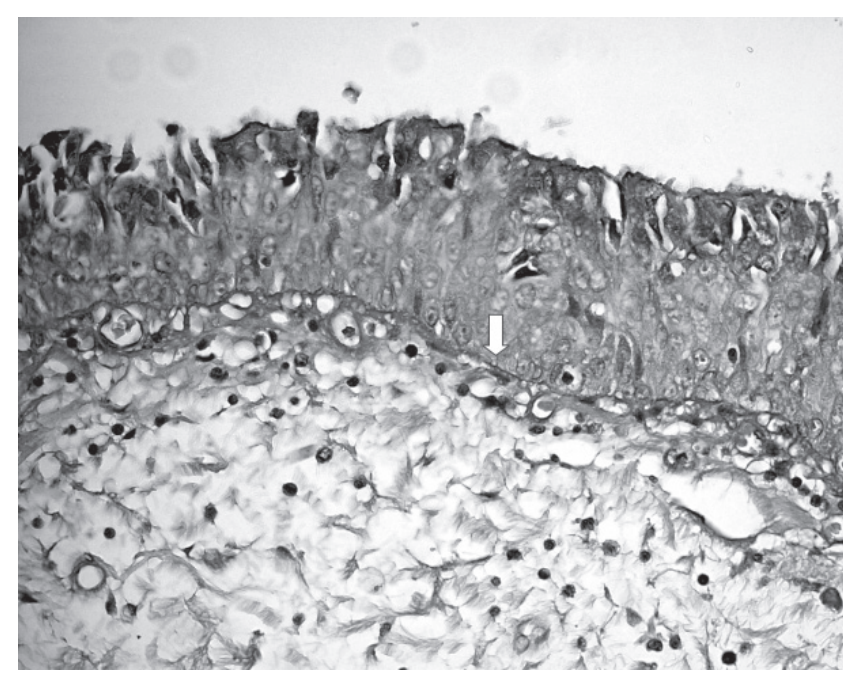

Figure 1 - Vocal cord with normal basal membrane thickening (arrow). The morphometric analysis was performed in 5 points (PASX40).

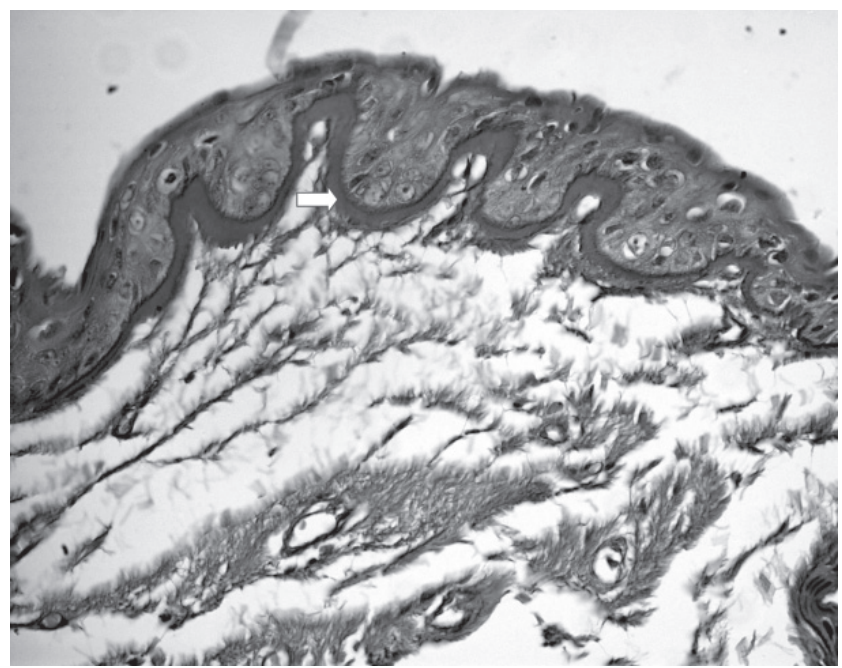

Figure 2 - Vocal-cord thickening basal membrane (arrow). The basal membrane thickening is not related with the cause of death and was diagnosed in $21.2 \%$ of the examined subjects (PASX40).

Table 3 - Type of vocal-cord lesion found in the subjects at autopsy and its relationship with respiratory and non-respiratory diseases as a cause of death.

\begin{tabular}{llllll}
\hline Cause of Death & Normal & Inflammation & Thickness & Hemorrhage & N (\%) \\
\hline Respiratory Diseases & 16 & 8 & 10 & 1 & $35(53)$ \\
NRDG Heart Diseases & 5 & 3 & 0 & 1 & $9(13.6)$ \\
Metastatic neoplasm & 1 & 3 & 1 & 1 & $6(9.0)$ \\
CNSH & 2 & 0 & 1 & 0 & $3(4.5)$ \\
Sepsis & 2 & 1 & 0 & 0 & $3(4.5)$ \\
Cirrhosis & 3 & 0 & 0 & 0 & $3(4.5)$ \\
Brain Edema & 2 & 0 & 0 & 0 & $2(3.0)$ \\
Neurotoxoplasmosis & 0 & 1 & 0 & 0 & $1.5)$ \\
Gastric Hemorrhage & 0 & 0 & 1 & 0 & $1(1.5)$ \\
$\quad$ Pancreatitis & 0 & 17 & $13 *$ & $3 *$ & $1.5)$ \\
$\quad$ Total & 31 & 0 &
\end{tabular}

*In these groups, we had a subject for which we could not find the medical record; CNSH = Central Nervous System Hemorrhage; NRDG = NonRespiratory Diseases Group. 
The basal membrane of the vocal cords is directly involved in various biological processes ${ }^{2}$. In adults, the thickening of the basal membrane of the vocal cords was found to be related to benign lesions of the vocal cords, most often in response to vibratory effects ${ }^{1,2}$, infectious diseases such as tuberculosis ${ }^{9}$, accidents or surgeries $^{10}$, and traumas from a variety of causes $^{9}$. In our study, the thickening of the basal membrane of the vocal cords was found most frequently in subjects whose cause of death was of respiratory alteration, among which were infectious causes such as pneumonia and tuberculosis.

In conclusion, this study shows that the thickening of the basal membrane of the vocal cords is frequent in adult subjects at autopsy. However, new studies are needed in order to verify the association of this thickening with diseases of the respiratory system.

\section{RESUMO}

SALGE AKM e col. - Avaliação Morfológica da membrana basal das cordas vocais de adultos autopsiados e sua correlação com as causas de óbito. Rev. Hosp. Clín. Fac. Med. S. Paulo 59(2):63-66, 2004.

OBJETIVO: O objetivo deste trabalho foi identificar as possíveis alterações na espessura da membrana basal das cordas vocais e relacionar estas com a causa de morte.

MÉTODO: Foram utilizadas laringes coletadas de adultos autopsiados, no período de 1993 até 2001. Realizamos as colorações da Hematoxilina-
Eosina e Ácido Periódico de Schiff, onde foi medido o diâmetro da membrana basal.

RESULTADOS: Foram analisadas 66 cordas vocais, o espessamento foi identificado em 14 casos $(21,2 \%)$, sendo encontrado em proporções iguais entre os sexos, sendo freqüente em pacientes da cor branca (12 casos, 85,7\%). Foram encontradas alterações respiratórias em $10(71,4 \%)$ dos casos com espessamento. Entre os pacientes intubados, $7(18,4 \%)$ apresentaram espessamento. Entre os fumantes $9(19,63 \%)$ apresentavam espessamento. Não houve influência estatisticamente significa- tiva do espessamento na doença que levou o indivíduo à morte.

CONCLUSÃO: Em relação a causa de morte não há diferença estatisticamente significante entre os casos cuja causa de morte foi por doenças respiratórias ou por doenças não respiratórias e o diagnóstico de espessamento da membrana basal das cordas vocais. Sua etiopatogênese necessita de maiores estudos.

UNITERMOS: Adultos. Autopsia. Corda vocal. Espessamento. Membrana basal.

\section{REFERENCES}

1. Dikkers FG, Hulstaert CE, Oosterbaan JÁ, et al. Ultrastructural changes of the basement membrane zone in benign lesions of the vocal folds. Acta Otolaryngol 1993; 113 (1): 98-101.

2. Cervera-Paz FJ, Dikkers FG. Ultrastructure and pathogenesis of vocal nodules on the vocal cords. Acta Otorrinolaringol Esp 1994; 45 (4): 261-265.

3. Courey MS, Shohet JÁ, Scott MA, et al. Immunohistochemical characterization of benign laryngeal lesions. Ann Otol Rhinol Laryngol 1996; 105 (7): 525-531.

4. Hollinshead W, Rosse C. In: Anatomia. Rio de Janeiro, Interlivros Edições, 1991. p. 839-856.

5. Katz SI. In: Basement membanes and cell movement. London, Pitman, 1984. p. 243-259.

6. Bach D, Peters A, Rowemeier H, et al. Anti-basal membrane glomerulonephritis after homologous kidney transplantation in hereditary Alport's nephropathy. Dtsch Med Wochenschr 1991; 116 (46): 1752-1756.

7. Castro ECC, Peres LC. Vocal cord basement membrane in nonsudden infant death syndrome cases. Ped Dev Pathol 1999; 2: 440-445.
8. Van Landeghem FK, Brinkmann B, Bajanowski T. Basement membrane thickness of the vocal cord in cases of sudden infant death. Int J Legal Med 1999; 12 (1): 31-41.

9. Moon WK, Han MH, Chang K, et al. Laryngeal tuberculosis: CT findings. Am J Roentgenol 1996; 166 (2): 445-449.

10. Milutinovic Z, Bojic P. Functional trauma of the vocal folds: classification and management strategies. Folia Phoniatr Logop 1996;. 48 (2): 78-85.

11. Fagan DG, Emery JL. A review and restatement of some problems in histological interpretation of the infant lung. Semin Diagn Pathol 1992; 9 (1): 13-23.

12. Valdes-Dapena M. Death investigation and post-mortem examination. In: Valdés-Dapena M, McFeeley PA, Hoffman HJ, et al. Histopathology Atlas for the Sudden Infant Death Syndrome. Washington, DC: Armed Forces Institute of Pathology, 1993. p. 23-37.

13. Cullity GJ, Emery JL. Ulceration and necrosis of vocal cords in hospital and unexpected child deaths. J Pathol 1975; 115: 27-31.

14. Shatz A, Hiss J, Arensburg B. Basement-membrane thickening of the vocal cords in sudden infant death syndrome. Laryngoscope 1994; 101: 484-486. 